\title{
MODEL PEMBELAJARAN SKEMA PADA PELAJARAN BAHASA INDONESIA DAPAT MENINGKATKAN KETERAMPILAN MEMBACA PEMAHAMAN TEKS ULASAN SISWA KELAS VIII MTS NEGERI BINJAI
}

\author{
Faridah Hayati Lubis
}

Surel: faridahhayati973@gmail.com

\begin{abstract}
This study aims to find out that the implementation of the schema learning model in Indonesian lessons can improve reading comprehension skills for grade VIII Madrasah Tsanawiyah Negeri Binjai students in the Odd Semesters of the 2019/2020 Academic Year. The results showed that the schema learning model in Indonesian lessons could improve reading comprehension skills. This can be seen from the results of the calculation in the first cycle between the value of the first daily test and the score of the second daily test, the Product Moment value is 0.823 with a t-test of 8.198. And the second cycle between the second block test scores and the third daily test scores obtained a Product Moment value of 0.903 with a t-test value of 11.902, while the results of the calculation showed that it was greater than the results in the table, of 0.478 and 2.725. Likewise, the average score for the first daily exam was 86.35, and the second daily exam was 87.53 in the first cycle, as well as the average score for the third daily exam was 88.53 and the fourth daily exam was 90.71 in the second cycle. there is an increase. while the minimum completeness criteria value (KKM is 84).
\end{abstract}

Keywords: Schematic Learning Model, Reading Comprehension Skills Review Text

\begin{abstract}
ABSTRAK
Penelitian ini bertujuan untuk Untuk mengetahui pelaksanaan model pembelajar an skema pada pelajaran bahasa indonesia dapat meningkatkan keterampilan membaca pemahaman teks ulasan siswa kelas VIII Madrasah Tsanawiyah Negeri Binjai Semester Ganjil Tahun Pelajaran 2019/2020. Hasil penelitian menunjukkan bahwa model pembelajaran skema pada pelajaran Bahasa Indonesia dapat meningkatkan keterampilan membaca pemahaman teks Ulasan. Hal ini dapat dilihat dari hasil hitung pada siklus pertama antara nilai ujian harian pertama dengan nilai ujian harian kedua diperoleh nilai Produc Moment sebesar 0,823 dengan uji t sebesar 8,198. Dan siklus kedua antara nilai ujian blok kedua dengan nilai ujian harian ketiga diperoleh nilai Produc Moment sebesar 0,903 dengan uji t nilai sebesar 11,902, sementara hasil hitung menunjukkan lebih besar dari hasil pada tabel, $r_{\text {tabel }}$ sebesar 0,478 dan $t_{\text {tabel }}$ sebesar 2,725. Begitu juga dengan nilai rata-rata ujian harian pertama sebesar 86,35, dan ujian harian kedua sebesar 87,53 pada siklus pertama, serta nilai rata-rata ujian harian ketiga sebesar 88,53 dan ujian harian keempat sebesar 90,71 pada siklus kedua terdapat peningkatan. sementara nilai kriteria ketuntasan minimal (KKM sebesar 84).
\end{abstract}

Kata Kunci: Model Pembelajaran Skema, Keterampilan Membaca Pemahaman Teks Ulasan. 
Faridah Hayati Lubis : Model Pembelajaran Skema ...

\section{PENDAHULUAN}

Dalam proses interaktif komunikatif antara sesama manusia ciptaan Tuhan digunakan Bahasa. Kemampuan memahami ciri-ciri bahasa ini akan menentukan berhasil tidaknya Anda dalam berkomunikasi. Keterampilan menyimak, berbicara, membaca, dan menulis termasuk di antaranya. Keempat talenta tersebut berbeda dalam hal mereka dapat berdiri sendiri, namun mereka terkait erat dalam hal menggunakan bahasa sebagai alat komunikasi. Hal ini menunjukkan bahwa bahasa merupakan gabungan dari berbagai unsur. Ada empat aspek berbahasa pada dasarnya merupakan satu kesatuan, keempat aspek tersebut merupakan catur tunggal yang sangat erat hubungannya dengan prosesproses berpikir yang melandasi bahasa. Salah satu aspek keterampilan berbahasa adalah keterampilan membaca. Membaca adalah alat untuk belajar dan untuk memperoleh kesenangan. Membaca merupakan alat untuk orang-orang yang melek huruf dalam memperoleh pengetahuan dan pengalaman yang telah disimpan ke bentuk tulisan. Pada tingkat yang lebih tinggi, membaca itu, bukan sekedar memahami lambang-lambang tertulis, melainkan pula memahami, menerima, menolak, membandingkan dan meyakini pendapat-pendapat yang ada dalam bacaan.

Buku adalah "gudang ilmu" begitu kata sebuah ungkapan. Tetapi apalah arti sebuah buku jika sama sekali tidak dibaca. Buku yang tidak dibaca ibarat sebuah gudang yang masih terkunci yang di dalamnya tersimpan berbagai harta yang sangat dibutuhkan. Penggunaan pendekat an, metode, dan teknik membaca yang tidak tepat diasumsikan merupakan salah satu faktor penentu kurang maksimalnya pencapaian tujuan membaca di sekolah. Selain itu, alokasi waktu yang disediakan untuk pembelajaran masih sangat minim. Akibatnya pelatihan-pelatihan yang diberikan oleh guru kepada siswa atau oleh fasilitator terhadap kiat-kiat pengembangan membaca yang baik juga disinyalir sangat kurang.

Pembelajaran membaca pemaham an menggunakan model pembelajaran skema sebagai salah satu upaya yang tepat karena dengan teknik skema peserta didik harus menghubungkan pengalamannya dengan pengalaman yang ada dalam buku teks terkhusus tentang teks ulasan. Untuk mengetahui seberapa jauh teknik skema dapat meningkatkan kemampuan peserta didik memahami teks bacaan, maka perlu diadakan penelitian tindakan, dengan judul sebagai berikut: Model Pembelajaran Skema Pada Pelajaran Bahasa Indonesia Dapat Meningkatkan Keterampilan Membaca Pemahaman Teks Ulasan Siswa Kelas VIII Madrasah Tsanawiyah Negeri Binjai Semester Ganjil Tahun Pelajaran 2019/2020.

Identifikasi Permasalahan, faktor pertama adalah dari faktor internal dan eksternal siswa didik, faktor peserta didik yang terdiri atas: (1) faktor internal antara lain 
rendahnya minat dan motivasi membaca, penguasaan Bahasa yang rendah, dan intelegensi peserta didik, dan (2) faktor eksternal antara lain : keadaan sosial ekonomi peserta didik, lingkungan yang kurang kondusif untuk peningkatan kemahiran membaca. Faktor kedua dipengaruhi dari fasilitator, faktor fasilitator antara lain: kemampuan fasilitator dalam memotivasi peserta didik, dan kemampuan fasilitator untuk mengola kelas dalam pembelajaran membaca yang masih kurang. Faktor-faktor tersebut perlu diulas dan dikaji agar dapat mengetahui permasalahan peserta didik dalam memahami pelajaran yang sedang diikuti nya, khususnya pembelajaran membaca teks editorial di tingkat sekolah menengah atas.

Tujuan penelitian ini adalah: Untuk mengetahui pelaksanaan model pembelajar an skema pada pelajaran bahasa indonesia dapat meningkatkan keterampilan mem baca pemahaman teks ulasan siswa kelas VIII Madrasah Tsanawiyah Negeri Binjai Semester Ganjil Tahun Pelajaran 2019/2020.

\section{METODE PENELITIAN}

Proses pelaksanaan penelitian tindakan kelas ini melibatkan siswa kelas VIII Madrasah Tsanawiyah Negeri Binjai Semester Ganjil Tahun Pelajaran 2019/2020 yang beralamat di jalan Pakan Baru no.2A Rambung Barat kecamatan Binjai Selatan kabupaten Binjai Kota Sumatera Utara, dan berjumlah 34 orang siswa, jumlah siswa laki-laki 18 orang dan siswa perempuan 16 orang yang diambil secara acak ditiap-tiap kelas VIII. Penelitian ini dilakukan dua siklus selama tiga bulan pada bulan Oktober sampai dengan Desember 2019, dengan siklus pertama dimulai pada bulan Otober 2019, dan dilakukan beberapa rincian sebagai berikut:

Perencanaan pertama, guru mempersiapkan RPP dan bahan ajar yang berkaitan dengan teks Ulasan, dan mengarahkan siswa untuk masuk ke kelas belajar seperti bisanya. Satu persatu siswa diabsensi, selanjutnya mempersilahkan siswa maju ke depan kelas bagi siswa yang sudah memperisapkan tugas yang telah diberikan sebelumnya, dan setelah beberapa siswa maju di depan kelas untuk membacakan hasil contoh teks Ulasan tersebut tanpa penggunaan model pembelajaran skema, maka diberikan apersepsi, dan pembelajaran membaca pemahaman teks Ulasan dengan cara biasa (pre test), dilanjutkan dengan pembagian kelompok sekaligus pembagian tugas.

Tindakan pertama, untuk memudahkan guru mempersiapkan kelompok diskusi sebanyak jumlah siswa, masing-masing siswa mendapat satu tugas yang bertuliskan penanya, penjawab, pengkritik, dan tanggapan terhadap kritik. Setiap satu siswa bertugas sesuai tugas yang diberikan oleh guru. Dengan demikian pembelajaran tidak berpusat kepada guru semata, tapi seluruh siswa aktif mendengarkan membaca teks ulasan temannya dan kreatif dalam memberikan pertanyaan, jawaban, kritik, dan tanggapan 
Faridah Hayati Lubis : Model Pembelajaran Skema ...

terhadap proses pembelajar an secara keseluruhan. Proses pembelajaran tetap diprioritaskan kepada kemampuan menemukan beberapa contoh teks ulasan yang telah ditemukan oleh siswa dan disampaikan secara bergiliran. Selanjutnya proses penilaian diberikan kepada seluruh siswa. Untuk penilaian materi membaca pemahaman teks ulasan didasarkan pada kemampuan siswa dalam menemukan beberapa contoh teks ulasan tersebut, sedangkaan bagi siswa lainnya diberikan penilaian sesuai dengan ketepatan pertanyaan, jawaban, kritik atau tanggapan yang disampaikan. Dalam perencanaan seluruh aspek penilaian terhadap materi membaca pemahaman teks ulasan tanpa menggunakan model pembelajaran Skema.

\section{(Observation)}

pertama,

Pengamat, seperti peneliti dan rekan, hadir untuk mengamati dan mengevaluasi aktivitas siswa selama mereka belajar. Bagaimana aktivitas siswa selama siswa membacakan hasil contoh teks Ulasan yang sudah dipersiapkan. Kesulitan - kesulitan yang diperoleh siswa pada saat membacakan hasil contoh teks Ulasan tersebut, yang tujuannya agar dapat diperbaiki pada saat pelaksanaan tindakan berikutnya.

\section{Refleksi}

(Reflection)

pertama, Pada tahap refleksi ini dilakukan analisis hasil belajar (postes 1), analisis hasil observasi aktivitas siswa dalam pembelajaran, dan mengkaji materi yang belum berhasil dituntaskan oleh siswa, dan hasilnya ditulis dibuku catatan singkat, yang akan digunakan sebagai gambaran kekurangan yang belum tuntas yang akan diperbaiki pada tindakan lanjutan berikutnya. Jika belum tuntas maka akan dilanjutkan pada siklus kedua atau siklus berikutnya. Penelitian berikut siklus kedua dimulai pada bulan November dan Desember 2019, dan dilakukan beberapa rincian sebagai berikut ;

Perencanaan kedua, pada pertemuan berikutnya guru bersikap positif terhadap apa yang diketahui siswa. Kehadiran siswa pada pertemuan sebelumnya berfungsi sebagai representasi visual dari apa yang sudah diketahui siswa pada saat itu, serta batu loncatan untuk mengembangkan konsep yang diperlukan. Guru dan siswa mendiskusikan materi yang akan disajikan. Guru memberikan petunjuk tentang bahan bacaan dan skema siswa dalam bentuk outline dan gambar. Materi yang akan diberikan dijelaskan oleh guru. Pada media berupa OHP, guru menampilkan tujuan pembelajaran dan judul bacaan. Perencanaan pada siklus kedua ini sudah menggunakan model pembelajaran skema pada pelajaran bahasa Indonesia tentang membaca pemahaman teks Ulasan.

Tindakan kedua, guru membimbing siswa menggunakan analogi perbandingan bahkan kalau perlu perbandingan metaforis untuk menjebatani apa yang telah siswa ketahui dengan hal-hal baru atau asing. Siswa menjawab judul bacaan. Setelah membaca teks ulasan, siswa 
menulis kata-kata yang sukar. Siswa diminta oleh guru untuk menanggapi judul wacana dalam teks ulasan. Guru telah membuat kerangka bagi siswa untuk menulis komentar mereka. Siswa diinstruksikan untuk membaca teks ulasan, menuliskan istilah yang sulit, dan kemudian mendiskusikan kata-kata tersebut, kemudian mencari kata kunci atau topik permasalahan dari suatu bacaan yang disesuaikan dengan judul dalam teks Ulasan tersebut.

(Observation) kedua, untuk mengetahui sejauhmana siswa telah memahami materi teks Usulan, maka guru memberikan contoh sebanyakbanyaknya mengenai konsep yang baru. Metaforis untuk menjembatani apa yang telah siswa ketahui dengan hal-hal baru atau asing. Guru mengarahkan siswa yang lain untuk memperhatikan dan menulis kekurangan-kekurangan yang terdapat dalam bacaan suatu teks Usulan sesuai dengan lampiran observasi yang telah disiapkan oleh guru.

Refleksi (Reflection) kedua, hasil obserrvasi yang telah dilakukan oleh guru bersama-sama siswa mencoba untuk memperbaiki kekurangan-kekurangan yang terdapat dalam bacaan suatu teks Usulan dengan cara siswa mengungkapkan ide pokok setiap paragraph, dan siswa menceritakan kembali isi teks dalam bahasa mereka sendiri. Kegiatan selanjutnya adalah Guru menginstruksikan siswa untuk menuliskan pada pokok-pokok pembahasan dan kemudian menggabungkannya menjadi paragraf yang logis dengan latihan-latihan yang dapat diselesaikan secara individu atau kelompok. Siswa diminta untuk menghubungkan jawaban siswa yang telah ditulis pada outline untuk memudahkan mereka memahami bacaan dan menemukan titik kunci (outline kegiatan). Hasil observasi yang dilakukan oleh guru hendaknya disampaikan ke siswa, guna perbaikan pada tindakan berikutnya.

\section{HASIL PENELITIAN DAN PEMBAHASAN}

Penelitian ini dilakukan di kelas VIII Madrasah Tsanawiyah Negeri Binjai Semester Ganjil Tahun Pelajaran 2019/2020 yang beralamat di jalan Pakan Baru no.2A Rambung Barat kecamatan Binjai Selatan kabupaten Binjai Kota Sumatera Utara, dan berjumlah 34 orang siswa, jumlah siswa laki-laki 18 orang dan siswa perempuan 16 orang yang diambil secara acak ditiap-tiap kelas VIII. Penelitian ini berlangsung selama kurang lebih tiga bulan yang dilaksanakan dari bulan Oktober sampai dengan bulan November 2019. Hasil yang diperoleh pada siklus pertama dengan nilai rata-rata ujian harian pertama sebesar 86,35 , dan ujian harian kedua sebesar 87,53, sementara pada siklus kedua dengan nilai rata-rata ujian harian ketiga sebesar 88,53 dan ujian harian keempat sebesar 90,71. dengan nilai kriteria ketuntasan minimal (KKM sebesar 84).

Berikut juga nilai korelasi antara nilai ujian harian pertama 
Faridah Hayati Lubis : Model Pembelajaran Skema ...

terhadap nilai ujian harian kedua pada siklus pertama sebesar 0,823 dengan nilai uji t sebesar 8,198, dan nilai korelasi antara nilai ujian harian ketiga terhadap nilai ujian harian keempat pada siklus kedua sebesar
0,903 dengan nilai uji $\mathrm{t}$ sebesar 11,902. Ini dapat dikatakan bahwa terdapat hubungan yang signifikansi. Hasil perhitungan di atas dapat dilihat pada tabel berikut:

Tabel 1. Hasil Perhitungan Siklus Pertama dan Siklus Kedua Tentang Model

Pembelajaran Skema Pada Pelajaran Bahasa Indonesia Dapat Meningkatkan Keterampilan Membaca Pemahaman Teks Ulasan Siswa Kelas VIII MTs Negeri Binjai Semester Ganjil Tahun Pelajaran 2019/2020

\begin{tabular}{|c|c|c|c|c|c|c|c|c|c|c|}
\hline No & $\mathrm{X} 1$ & $\mathrm{X} 1 . \mathrm{X} 1$ & Y1 & Y1.Y1 & X1.Y1 & $\mathrm{X} 2$ & $\mathrm{X} 2 . \mathrm{X} 2$ & $\mathrm{Y} 2$ & Y2.Y2 & $\mathrm{X} 2 . \mathrm{Y} 2$ \\
\hline 1 & 87 & 7569 & 88 & 7744 & 7656 & 89 & 7921 & 91 & 8281 & 8099 \\
\hline 2 & 85 & 7225 & 86 & 7396 & 7310 & 87 & 7569 & 89 & 7921 & 7743 \\
\hline 3 & 91 & 8281 & 92 & 8464 & 8372 & 93 & 8649 & 95 & 9025 & 8835 \\
\hline 4 & 86 & 7396 & 87 & 7569 & 7482 & 88 & 7744 & 90 & 8100 & 7920 \\
\hline 5 & 86 & 7396 & 87 & 7569 & 7482 & 88 & 7744 & 90 & 8100 & 7920 \\
\hline 6 & 87 & 7569 & 88 & 7744 & 7656 & 89 & 7921 & 91 & 8281 & 8099 \\
\hline 7 & 86 & 7396 & 87 & 7569 & 7482 & 88 & 7744 & 90 & 8100 & 7920 \\
\hline 8 & 86 & 7396 & 87 & 7569 & 7482 & 88 & 7744 & 90 & 8100 & 7920 \\
\hline 9 & 82 & 6724 & 84 & 7056 & 6888 & 85 & 7225 & 87 & 7569 & 7395 \\
\hline 10 & 86 & 7396 & 87 & 7569 & 7482 & 88 & 7744 & 90 & 8100 & 7920 \\
\hline 11 & 86 & 7396 & 87 & 7569 & 7482 & 88 & 7744 & 90 & 8100 & 7920 \\
\hline 12 & 86 & 7396 & 88 & 7744 & 7568 & 89 & 7921 & 91 & 8281 & 8099 \\
\hline 13 & 86 & 7396 & 87 & 7569 & 7482 & 88 & 7744 & 90 & 8100 & 7920 \\
\hline 14 & 88 & 7744 & 89 & 7921 & 7832 & 90 & 8100 & 92 & 8464 & 8280 \\
\hline 15 & 85 & 7225 & 86 & 7396 & 7310 & 87 & 7569 & 89 & 7921 & 7743 \\
\hline 16 & 85 & 7225 & 86 & 7396 & 7310 & 87 & 7569 & 89 & 7921 & 7743 \\
\hline 17 & 85 & 7225 & 86 & 7396 & 7310 & 87 & 7569 & 89 & 7921 & 7743 \\
\hline 18 & 85 & 7225 & 86 & 7396 & 7310 & 87 & 7569 & 89 & 7921 & 7743 \\
\hline 19 & 85 & 7225 & 86 & 7396 & 7310 & 87 & 7569 & 94 & 8836 & 8178 \\
\hline 20 & 85 & 7225 & 86 & 7396 & 7310 & 87 & 7569 & 89 & 7921 & 7743 \\
\hline 21 & 89 & 7921 & 90 & 8100 & 8010 & 91 & 8281 & 93 & 8649 & 8463 \\
\hline 22 & 86 & 7396 & 87 & 7569 & 7482 & 88 & 7744 & 90 & 8100 & 7920 \\
\hline 23 & 88 & 7744 & 89 & 7921 & 7832 & 90 & 8100 & 92 & 8464 & 8280 \\
\hline 24 & 87 & 7569 & 88 & 7744 & 7656 & 89 & 7921 & 92 & 8464 & 8188 \\
\hline 25 & 87 & 7569 & 88 & 7744 & 7656 & 89 & 7921 & 91 & 8281 & 8099 \\
\hline 26 & 88 & 7744 & 89 & 7921 & 7832 & 90 & 8100 & 92 & 8464 & 8280 \\
\hline 27 & 90 & 8100 & 91 & 8281 & 8190 & 92 & 8464 & 94 & 8836 & 8648 \\
\hline 28 & 87 & 7569 & 88 & 7744 & 7656 & 89 & 7921 & 91 & 8281 & 8099 \\
\hline 29 & 87 & 7569 & 88 & 7744 & 7656 & 89 & 7921 & 91 & 8281 & 8099 \\
\hline 30 & 80 & 6400 & 84 & 7056 & 6720 & 85 & 7225 & 87 & 7569 & 7395 \\
\hline 31 & 86 & 7396 & 87 & 7569 & 7482 & 88 & 7744 & 90 & 8100 & 7920 \\
\hline 32 & 91 & 8281 & 92 & 8464 & 8372 & 93 & 8649 & 95 & 9025 & 8835 \\
\hline 33 & 89 & 7921 & 90 & 8100 & 8010 & 91 & 8281 & 93 & 8649 & 8463 \\
\hline 34 & 83 & 6889 & 85 & 7225 & 7055 & 86 & 7396 & 88 & 7744 & 7568 \\
\hline & 2936 & $\begin{array}{c}25369 \\
8 \\
\end{array}$ & 2976 & $\begin{array}{c}26061 \\
0\end{array}$ & $\begin{array}{c}25712 \\
5 \\
\end{array}$ & 3010 & $\begin{array}{c}26659 \\
6 \\
\end{array}$ & 3084 & $\begin{array}{c}27987 \\
0 \\
\end{array}$ & $\begin{array}{c}27314 \\
0 \\
\end{array}$ \\
\hline & 86,35 & & 87,53 & \multicolumn{2}{|c|}{$r=0,823$} & 88,53 & & 90,71 & \multicolumn{2}{|c|}{$r=0,903$} \\
\hline & & & & \multicolumn{2}{|c|}{$\mathrm{t}=8,198$} & & & & \multicolumn{2}{|c|}{$t=11,902$} \\
\hline
\end{tabular}

Sumber : Data primer yang diolah

Pembahasan

Membaca merupakan tindakan aktif yang memerlukan pemahaman terhadap apa yang telah dibaca dalam suatu bacaan. Membaca tidak hanya berarti 
memahami lambang-lambang tertulis tetapi juga memahami, menerima, menolak, membandingkan, dan meyakini pendapat pembaca. Belajar membaca dan memahami teks ulasan menggunakan teknik skema merupakan salah satu upaya terbaik karena menuntut siswa untuk menghubungkan pengalaman pribadi mereka dengan pengalaman kelas. Teknik skema dapat digunakan untuk menerapkan model pembelajaran pada tindakan membaca wacana dalam teks bacaan resensi. Hal ini dimaksudkan agar penggunaan teknik skema akan memudahkan siswa dalam memahami substansi suatu wacana.

Berdasarkan tabel 1 di atas tentang Hasil Belajar Siswa dapat diartikan bahwa terdapat peningkatan nilai ujian harian pada siklus pertama meningkat yaitu nilai rata-rata ujian harian pertama sebesar 86,35, dan ujian harian kedua sebesar 87,53, sedangkan pada siklus kedua nilai rata-rata ujian harian ketiga sebesar 88,53 dan ujian harian keempat sebesar 90,71. Ini dapat dilihat pada diagram batang berikut:

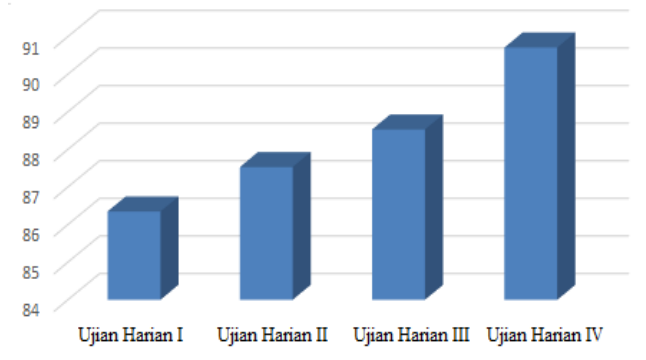

Gambar 1. Nilai Rata-rata Hasil Belajar Bahasa Indonesia

Berdasarkan diagram batang di atas artinya terdapat peningkatan pada nilai rata-rata ujian harian baik di siklus pertama mau pun siklus kedua, artinya dikategorikan sangat signifikansi. Begitu juga terdapat peningkatan absensi kehadiran siswa disaat mengikuti kegiatan penelitian tindakan kelas (PTK) yang dilakukan selama tiga bulan, dari bulan Oktober, November dan Desember 2019, yang dapat dilihat pada diagram batang berikut:

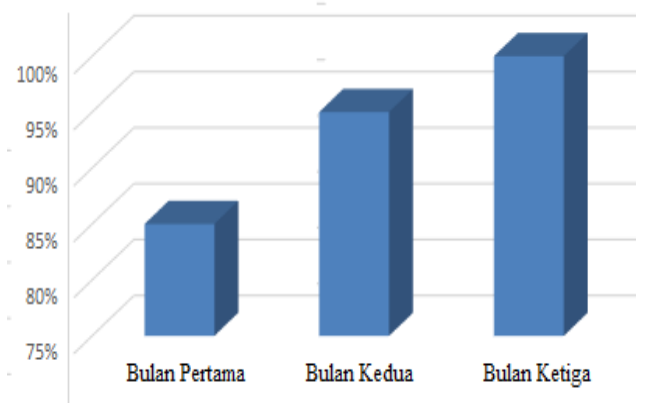

\section{Gambar 2. Hasil Kehadiran Belajar Bahasa Indonesia Selama PTK}

Berdasarkan diagram batang di atas artinya terdapat peningkatan pada kehadiran siswa pada siklus pertama $85 \%$, meningkat menjadi 95\% dan $100 \%$ pada siklus kedua., artinya siswa semakin aktif dalam mengikuti kegiatan tersebut.

\section{SIMPULAN}

Berdasarkan hasil analisis data yang telah di bahas pada penjelasan di atas, maka dapat ditarik kesimpulan bahwa model pembelajaran skema pada pelajaran Bahasa Indonesia dapat meningkatkan keterampilan membaca pemahaman Teks Ulasan siswa kelas VIII Madrasah Tsanawiyah Negeri Binjai Semester 
Faridah Hayati Lubis : Model Pembelajaran Skema ...

Ganjil Tahun Pelajaran 2019/2020, hal ini dapat dilihat dari hasil hitung nilai korelasi antara nilai ujian harian pertama terhadap nilai ujian harian kedua pada siklus pertama sebesar 0,823 dengan nilai uji $\mathrm{t}$ sebesar 8,198 , dan nilai korelasi antara nilai ujian harian ketiga terhadap nilai ujian harian keempat pada siklus kedua sebesar 0,903 dengan nilai uji t sebesar 11,902, artinya dikategorikan sangat signifikansi.

\section{DAFTAR RUJUKAN}

Arikunto, Suharsimi. 2018. Penelitian Tindakan Kela., Medan: Dalam Seminar Pendidikan di Medan
Depdiknas. 2001. Kamus Besar Indonesia. Jakarta: Balai Pustaka

Depdiknas. 2003. Kurikulum Berbasis Kompetensi. Jakarta: Depdiknas

Depdiknas, 2003. Undang-Undang Republik Indonesia Nomor 20 Tahun 2003 Tentang system Pendidikan Nasional. Jakarta: Depdiknas

Saifuddin Azwar. 2000. Reliabilitas dan Validitas. Yogjakarta: Pustaka Pelajar.

Tim Redaksi. 2005. Kamus Besar Bahasa Indonesia. Jakarta: Balai Pustaka. 